\title{
OUTRAS CENAS DO QUEER À BRASILEIRA: UMA INCURSÃO SOBRE ARTES E GEOPOLÍTICAS QUEER NO BRASIL $^{1}$
}

\section{OTHER SCENES OF THE BRAZILIAN QUEER: AN INCURSION IN THE ARTS AND QUEER GEOPOLITICAL IN BRAZIL}

Tiago dos Santos de Sant'Ana ${ }^{2}$

\section{RESUMO}

Este texto tem como objetivo colaborar com o esforço de revelar e discutir uma possível genealogia das políticas queer no Brasil. A pesquisa propõe um deslocamento do que se tem escrito nesse campo de conhecimento, primeiro, por entender que a historiografia do queer no Brasil se dá de maneira regionalizada - tomando colonialmente o Sul e Sudeste como centro legítimo; e, segundo, por negligenciar o papel da arte na composição de sua historiografia. Para tal, será debatido o trabalho do cineasta tropicalista Jomard Muniz de Britto, que traz consigo uma potência para pensar numa política de gênero e sexualidade de modo dissidente e no Nordeste.

Palavras-chave: Políticas Queer. Queer no Brasil. Arte. Jomard Muniz de Britto. Nordeste.

\footnotetext{
${ }^{1}$ Este texto reúne fragmentos da minha dissertação intitulada "Outras cenas do queer à brasileira: o grito gongadeiro de Jomard Muniz de Britto no cinema da Recinfernália", orientada pelo professor Leandro Colling. No trabalho, através de materiais de arquivo, conversas e de filmes, discuto como a produção do cineasta pernambucano, iniciada na década de 1970, se descortina como um potente material de imersão para pensar numa produção artística insurgente.

${ }^{2}$ Mestre em Cultura e Sociedade pela Universidade Federal da Bahia (UFBA). Integra o grupo de pesquisa CUS - Cultura e Sexualidade. Email: tiago.santana.jornalismo@gmail.com
} 


\begin{abstract}
This text aims to collaborate with the effort to reveal and discuss a possible genealogy of the queer politics in Brazil. The research proposes a shift in what has been written in this field of knowledge, first by understanding that the history of queer in Brazil is regionalized - colonially taking the South and the Southeast as legitimate center; and, second, by understanding the negligence about role of art in the composition of the queer historiography. To this end, will be discussed the work of tropicalista filmmaker Jomard Muniz de Britto which brings with it a power to think in gender and sexual politics starting from a perspective dissident and in the Northeast.
\end{abstract}

Keywords: Queer Politics. Brazil Queer. Art. Jomard Muniz de Britto. Northeast. 


\section{Introdução}

Uma pessoa negra que explicitamente possui uma performatividade que transita entre os gêneros desce a escadaria de uma casa. Sua imagem é alternada com frames de um mar azul e tropical. Uma narrativa em voz off se desenrola e aborda assuntos como raça, Candomblé e violência. Incorporações. Dupla incorporação. Uma entidade e um corpo (des)feito. Um encontro entre a tradição matricial afro-brasileira e a aceitação de um gênero inconforme. Uma fantasia de carnaval brilhante e opulenta surge na tela. Maria Aparecida se enfeita e colore a cara. O destino dela é um macaratu, sincrético e resistente. A festa acontece, profana e nervosa. A identidade carnavalesca de Maria é embebida por ruídos de super- $8^{3}$. Estetiza-se, resiste e subverte. Essa descrição, realizada ainda superficialmente, é do filme "Maria Aparecida no carnaval". O diretor, Jomard Muniz de Britto, parece querer mostrar a possibilidade de enfrentamentos de distintas identidades. Maria Aparecida é transvesti ${ }^{4}$-negra-candomblecista-carnavalesca-resistente. Seria uma interessante subjetividade para por em questão debates que tem como ponto principal a indagação sobre identidades interseccionais e fragmentadas - temática tão em voga dentro da academia brasileira via, por exemplo, Estudos Culturais. O filme, de 1974, sem pretensões de ser didático, nos fala da alegria como resistência às violências a que somos constantemente submetidas. A obra traz uma potência de imagens que discursam. E, para além disso, nos revela a intenção do artista e de Maria Aparecida em nos avisar que é possível viver sem ter como referenciais os padrões políticos e identitários propagados naquele momento em que a Ditadura Militar no Brasil revelava sua face mais nefanda. Jomard Muniz de Britto $^{5}$ é um dos responsáveis pelo pensamento tropicalista no Nordeste. Publicou dois manifestos que reivindicam a não assimilação social e econômica da arte. Participou do

\footnotetext{
${ }^{3}$ É chamada de super-8 a bitola que surge nos Estados Unidos nos anos de 1960, um tipo de filmagem mais barato e ágil para registros familiares. No Brasil, mais que uma modalidade cinematográfica, o super- 8 foi o suporte de experimentação de uma geração de cineastas associados à contracultura. $\mathrm{O}$ super-8 era o modo de contestação política e estética de um grupo de artistas, sobretudo, no Nordeste do Brasil.

${ }^{4}$ É uma autodenominação de Maria Aparecida, que replicamos do mesmo modo, já que é assim que ela reivindica sua identidade de gênero.

${ }^{5}$ Doravante JMB ou mau velhinho. Ele mesmo se nomeia como "JMB, o famigerado", além de "o mau velhinho" - numa rápida oposição à sua imagem afável de cabelos grisalhos penteados para trás, olhos redondos que portam sempre óculos de aros grossos escuros.
} 
programa pedagógico de Paulo Freire e foi perseguido e preso por ser considerado comunista - já que defendia a educação e a arte como ferramentas mobilizadoras e de transformação social.

Mais de 40 anos depois de produzido, "Maria Aparecida no carnaval" é o meu ponto inicial nesta investigação. Que tipo de inquietação existia naquele período para que um cineasta produzisse algo que mesmo hoje é um assunto tão recorrente? Em que medida produções culturais podem ser indicativas dos contextos históricos ao qual estão inseridas? Existe política de gênero e sexualidade dentro da arte? A arte pode construir uma política de gênero e sexualidade a partir de referenciais dissidentes? O que produções culturais podem trazer de diferente e quais as potências políticas delas no combate às opressões de gênero e sexualidade?

\section{Para início de conversa}

Este texto tem como principal ensejo pensar como a perspectiva queer no Brasil vem sendo comentada dentro da universidade e lançar um olhar crítico a esses processos. A crítica parte com base nos resultados da minha pesquisa de mestrado onde identifiquei uma negligência quando se tenta compor no Brasil uma historiografia da perspectiva queer. Mas, antes disso, vale entender as bases que constroem as barricadas dessa posição política.

A perspectiva queer está ligada profundamente ao momento de intensa luta pelos direitos civis de pessoas LGBTs no início da década de 1980 , sobretudo, em decorrência do avanço da AIDS nos Estados Unidos. O queer traz para o campo uma gama de diferentes formas de reflexão e ação em relação ao que se tem chamado de "militância tradicional" ou "militância mais institucionalizada". "Queer" reinvidica o insulto para si, como uma forma de se opor à normalização que o movimento LGBT tradicional estava desejando para si. "Queer pode ser traduzido como raro, excêntrico, estranho” (LOURO, 2004, p. 39) e é nessa própria ideia de "estranhar" que essa posição se baseia.

Ao apontar o surgimento sociopolítico do queer, Javier Sáez (2007, p. 67) apregoa que "a crise da AIDS, a crise do feminismo heterocentrado, branco e colonial e a crise cultural advinda da assimilação pelo sistema 
capitalista da incipiente cultura gay"6 compõem um conjunto de fatores primordiais para formar uma frente que muda o olhar para a realidade social de pessoas não-heterossexuais daquele período.

Nesse sentido, a distinção fundamental para entender o ponto de inflexão que o queer propõe é a desconstrução da ideia de essência e ao paradigma da igualdade. Os movimentos LGBTs tradicionais, desde os anos 1970, propõe esse modelo de integração a todo custo, ao qual Sáez (2007) aponta como um dos motivos da emergência do queer. A política queer, ao contrário, defende que é a diferença que produz políticas de respeito e alcance a demandas sociais específicas. Ou, dito de outro modo, é preciso entender as diferentes subjetividades para construir políticas que possam atender suas necessidades próprias. Sem contar que na história do movimento de diversidade sexual existe a supremacia da identidade gay frente a outras diferentes marcas de gênero e sexualidade - ou, como se convenciona chamar atualmente, de movimento GGGG. O essencialismo se converte numa cilada por insistir em verdades sobre os sexos e os gêneros, tentando explicar objetivamente o que seria gay, lésbica, bissexual ou travesti - sem deixar chances para trânsitos ou fraturas que ponham em questão essas identidades.

Aliás, uma ideia que é cara para a política queer é apontar como as relações sociais e as práticas culturais estão longe de serem naturais, mas sim construções sociais dentro de teias de poder. Esse ponto é importante, pois foi dado ao discurso da medicina, da biologia e da cientificidade a autoridade para nomear os corpos e as subjetividades. Há uma norma pautada na obediência, na virtude, na consciência e numa lei (natural, humana ou divina). O poder da palavra que era dado à Igreja, na Idade Média, foi aos poucos sendo compartilhado com a ciência, que tratou logo de definir os padrões de normalidade e anormalidade. A transposição da heterossexualidade, que já era condenada pela religião católica, passou a ser destrinchada com o olhar das ciências biológicas e psicológicas, que legitimavam a naturalidade

\footnotetext{
${ }^{6}$ Trecho original: "la crisis del SIDA, la crisis del feminismo heterocentrado, blanco y colonial, y la crisis cultural derivada de la asimilación por el sistema capitalista de la inicipiente cultura gay".
} 
da heterossexualidade em detrimento do exotismo e anormalidade de outras experiências sexuais.

Leandro Colling (2013) aponta que a diferença fundamental para entendermos as divergências entre um movimento LGBT mais institucionalizado e uma política mais queer é a adesão a um paradigma da igualdade. Os movimentos identitários mainstream utilizam como estratégia no fomento à "diversidade sexual e de gênero" um essencialismo estratégico, pautado numa afirmação homogeneizante de uma identidade coletiva. Colling (idem) alerta que isso é perigoso já que muitas pessoas carregam consigo diferenças que põem em questão as verdades dessas identidades. Ou seja, para o movimento LGBT "tradicional" mais vale a afirmação identitária - que concederia direitos a um grupo homogêneo e delimitado de pessoas - do que a problematização da naturalização das diferenças. Uma política de dissidência sexual e de gênero insiste, ao contrário, numa estratégia de cruzamentos de demandas sociais, desconstruindo discursos naturalizantes e minando discursivamente os binarismos.

Voltando à contextualização, os acirramentos sobre o queer chegam à academia estadunidense por meio de pessoas que integravam coletivos não-assimilacionistas e, ao mesmo tempo, ocupavam lugares como estudantes ou docentes dentro das universidades. O nome "Teoria queer" foi utilizado pela primeira vez em 1990 na Califórnia numa conferência proferida por Teresa de Lauretis (MISKOLCI, 2009). Ela põe em jogo a heterossexualidade para ressaltar o quanto, no processo histórico das sexualidades, algumas subjetividades foram jogadas para o campo da patologia e da inumanidade. Os estudos sobre a diferença começam a ebulir como um horizonte de poder estranhar a ciência e os estudos tais quais estavam sendo alcançados até então. Estudos sobre gênero, sexualidade e outros marcadores sociais da diferença, como a raça e a classe, se intensificam e se disseminam, ancorados, sobretudo, nos pensamentos sobre o poder e o discurso de Michel Foucault, sobre a linguagem de Jacques Derrida, além dos enfrentamentos propostos por Gilles Deleuze e Félix Guattari.

Partindo disso, Judith Butler (2001) reflete como a sociedade aplica um sistema coercitivo que normatiza e hierarquiza o "sexo" por meio de sistemas de regulação. A filósofa traz à tona a questão do corpo discursivo, que já não apenas é compreendido por um viés estritamente biológico, mas sim dentro de complexos contextos discursivos e, 
consequentemente, de poder. Butler (idem) aponta o sexo como um ideal regulatório, sendo uma construção que se materializa ao longo do tempo por meio da reiteração ritualizada das normas. Elas são propagadas dia após dia para que um resultado efetivo seja executado nos corpos. Essas reiterações agem no corpo - que é tido como referência de deliberação dos lugares sociais, da posição do indivíduo no interior de um grupo. Ele é significado culturalmente e suas características se tornam marcas (LOURO, 2004). Marcas que identificam e hierarquizam os sujeitos como importantes ou não.

Toda essa ebulição dos estudos queer - ao questionar a norma, ao rejeitar cânones da universidade, pondo em tensão autores sacralizados - tem reverberação no Brasil em fins dos anos de 1990. Miskolci (2011) aponta que um dos marcos dos estudos queer no Brasil é o artigo "Teoria queer: uma política pós-identitária para a educação" de Guacira Lopes Louro (2001) publicado na Revista Estudos Feministas. Atualmente, essa visão alcança um crescente interesse por parte da universidade, que se esmera em apontar as potencialidades e os limites do queer. Além de uma também crescente produção de reportagens e produtos culturais tendo como norte essa perspectiva.

Com o fortalecimento do queer no Brasil, um conjunto de tensões foi e ainda está sendo levantado pela militância mais institucionalizada quanto à eficácia de uma política queer pautada na ideia de diferença. Em mesa redonda realizada no congresso da Associação Brasileira de Estudos da Homocultura (ABEH), Colling (2010) criticou uma possível dicotomia entre movimento LGBT e pesquisadores/ "militantes" queer. Segundo ele, o que a perspectiva queer faz é construir uma série de críticas à maneira como a militância tradicional atua, o que não quer dizer o extermínio dela. Entre os limites apontados por Colling (2010) está o investimento único em políticas institucionais de combate às opressões de sexualidade e gênero - sem existir um programa continuado e intensivo de educação e cultura que possa rever a visão social acerca do respeito às diferenças. Além disso, cita também dois outros pontos que já tratei anteriormente, que estão relacionados ao projeto que dá início aos ideais queer: o modelo normativo ao qual a militância enquadra as comunidades não-heterossexuais, além do padrão bom mocista que se espera de um gay que deseja ser integrado à sociedade. Colling assevera que "enquanto a heterossexualidade não for problematizada como uma imposição, como uma construção, a 
homofobia e a falta de respeito à diversidade sexual e de gênero não vão acabar" (2010, p. 7). Ao contrário, os movimentos LGBTs mais institucionalizados não costumam incomodar e mantém o status quo heterossexual intocado.

Internamente, no Brasil, um dos principais limites elencados em relação à política queer é que essa é uma visão de estudos estrangeiros, advindos dos Estados Unidos, um país hegemônico e imperialista, além da própria impossibilidade de se falar em Brasil quando se fala em "queer". E quais as implicações políticas que esse queer pode ter no Brasil? É plausível que uma teoria estrangeira, embasada em linhas gerais por pensadores da Europa e dos Estados Unidos, possa ser utilizada por pesquisas do Brasil? Ou melhor, uma "teoria" estadunidense/europeia quando utilizada por pessoas "dos trópicos" não reiteraria a ordem global que subalterniza essa região? O que sobra do queer depois da decolonização? Conseguimos falar de um queer a brasileira? É cabível perguntar se em algum momento já fomos queer no Brasil antes mesmo do surgimento do queer? O queer dentro de produtos culturais é uma realidade? Trazendo para nosso caso específico, Jomard Muniz de Britto poderia ser considerado um produtor de um prelúdio do queer - já que traz uma série de articulações que são caros para essa política mesmo hoje?

\section{Queer brasilis}

Nos últimos anos, um grupo ainda pequeno de pessoas ligadas aos estudos queer se debruça em textos e pesquisas para tentar purpurinar ainda mais o queer com cores brasileiras. Miskolci (2009), Pelúcio (2012, 2014), Benetti (2013), Colling (2014) e Pereira (2012) são algumas pessoas que vem erigindo esse tipo de investigação no nosso país.

Benetti (2013) realiza um trabalho exaustivo em que tece uma historiografia, de maneira quantitativa, da emergência dos estudos queer no Brasil desde 1980 até 2013. O pesquisador argumenta que essa posição tem sido revista por diversos lugares do mundo e que no Brasil começa a ter uma inserção maior nos anos 2000 por meio de periódicos, livros e congressos. 
Um dos meus destaques ao texto de Benetti (2013) é como ele identifica alguns textos considerados "clássicos" do movimento homossexual brasileiro sendo veículos de discursos que já anunciavam algo de queer. Um exemplo é quando Benetti cita o texto de Peter Fry, sobre o $1^{\text {o }}$ Encontro Nacional de Grupos Homossexuais em São Paulo, em que participantes criticavam o modo pelo qual suas relações estavam sempre pautadas dentro de binarismos como "ativo/passivo", "fanchona/lady". (2013, p. 36). Além disso, cita o jornal "Lampião da esquina" como um potente veículo de uma crítica aos padrões da heterossexualidade. Benetti (2013) alerta que o Lampião traz certas publicações que esgrimem a desnaturalização da heterossexualidade ou a desconstrução dos binarismos nos anos de 1970, quando o queer é ainda embrionário. Ainda que eu reconheça o trabalho de Benetti, a sua historiografia queer só recorre a textos acadêmicos, em publicações igualmente acadêmicas para nos falar sobre uma genealogia.

Miskolci (2014) também parece seguir uma linha de investigar a possibilidade de um queer a brasileira questionando "[...] por que ao invés do diálogo crítico e criativo, adaptado à nossa realidade, ainda vigora uma tendência à incorporação de temas, conceitos e teorias alheios aos nossos contextos particulares?" (MISKOLCI, 2014, p. 14). Ele mesmo afirma que ainda não consegue dar resposta a esse questionamento, sobretudo porque há uma economia-política do conhecimento que supervaloriza as produções elaboradas ao norte do globo em detrimento de outras localidades subalternizadas historicamente. A sugestão de Miskolci (idem) é que o queer possa encarnar uma habilidade contra-disciplinar ou, como sugeriria Sáez (2007), ser uma política de resistência e não necessariamente de libertação. Os estudos e a política queer deveriam, portanto, compor intercâmbios entre as diversas áreas do conhecimento e ressaltar a área de conhecimento queer como um saber insurgente.

Pedro Paulo Pereira (2012) também traz em sua trajetória recente inquietações que tentam dar conta desse queer à brasileira. O pesquisador aventa que é necessário pensar na política queer fora das zonas centro-orientadas, traçando uma tradução dessa perspectiva para a realidade local. O queer deve se embeber dos contextos locais e nas potencialidades das vivências subversivas de "outras zonas". De tal modo, o próprio termo queer, um vocábulo do idioma anglo-saxão, adquiria uma resistência a qualquer tipo de tradução fácil e 
uniformizante, consistindo numa palavra vinculada com a própria impossibilidade de se delimitar. A estranheza estaria presente no processo linguístico, forçando a uma outra gramática. (PEREIRA, 2012). O autor aponta como os corpos queer burlam a norma e propõe subjetividades fronteiriças, que se rearticulam e reinventam conforme as normas e as tecnologias de produção dos sexos. Queer estaria, portanto, circunscrito no desafio de se rebelar contra a adequação em características da normalidade e da anormalidade, extrapolando os limites discursivos e materiais dos corpos/sexos.

Pereira (2012) imerge na realidade das travestis que são praticantes de religiões afro-brasileiras para perceber as diversas formas de agenciamento do corpo, que burlam regras e certames da hetenormatividade. Os arquétipos das religiões são utilizados como explicação para a mudança corporal das travestis, que performam um gênero fronteiriço e que são glorificadas naqueles contextos litúrgicos. As religiões dariam, portanto, uma nova gramática para essas travestis, já que agenciam outras subjetividades. O trânsito é entendido como experiência sexual dentro das religiões afro-brasileiras e, por isso, essas travestis encontram nos signos místicos a representação das suas diferenças.

Essa pesquisa de Pereira (2012), especificamente, traz consigo algo muito interessante para minha observação. O filme "Maria Aparecida no carnaval" traz em seu contexto exatamente as indagações que Pereira (2012) traça em seu texto. Questões que envolvem incorporação, papéis de gênero e a transformação de matricialidades através das identidades de gênero e sexuais. Esse talvez seja o exemplo mais explícito de como os filmes de JMB também parecem preludiar o que hoje se chama de queer. E, mais que isso, já indica a potência de um intercâmbio entre as questões de gênero, sexualidade e de decolonidade.

Colling (2014) apregoa que existe um crescimento de trabalhos acadêmicos que tratam sobre sexualidade e gênero tendo como referencial as concepções queer. Contudo, o pesquisador aponta que existe um grande hiato entre o conhecimento produzido e um impacto real em políticas da diferença no que tange sexualidade e gênero. Dentre algumas das presumíveis causas para isso, Colling (idem) aponta a maneira ineficaz dessas ideais engendradas na universidade atingirem uma população não necessariamente letrada e que não tem vínculo com o meio acadêmico. $O$ pesquisador crítica a forma com que a produção 
de pesquisadores tem se configurado - através de linguagens e procedimentos metodológicos arcaicos, que, inclusive, por diversas vezes, reiteram modelos de procedimento normativos que, outrora, oprimiram pessoas não-normativas.

Como uma possível escapatória a isso, Colling (idem) aponta a probabilidade de produtos culturais que abordem as questões de gênero e sexualidade, contudo, de forma provocativa e de mais fácil compreensão para um público mais amplo. Imagino que esse caminho apontado por Colling talvez já fosse compreendido por alguns artistas e agitadores culturais que faziam de suas produções estandartes de exaltação de uma marginalidade que criticava a obrigatoriedade de modelos de sexualidade e família.

Apesar de todos esses aspectos levantados por essas/es autoras/es, ainda penso que a discussão se centra de maneira primordial dentro dos ambientes acadêmicos e sem levar em consideração uma série de produções que não flertam com o modelo de fazer universidade, pautada em produtividade em detrimento de qualidade e enfrentamento teórico. Ademais, cabe ressaltar que o fenômeno do "queer a brasileira" não é visto de maneira consensual por essas pessoas pesquisadoras. Tentarei identificar algumas dessas distinções abaixo tomando como exemplo a visão de Miskolci (2015a) e Colling (2015) sobre a mesma pergunta: "Sempre fomos queer?", proposta pelo I Seminário Desfazendo Gênero no ano de 2013.

Miskolci (2015a) aponta que desde o início da "Teoria Queer" nessas terras sempre foram criados "filtros" para refletir sobre a problemática daqui. O pesquisador olha para a saúde, a educação e a pesquisa acadêmica para falar numa desestabilização da ideia de nação, que vai influenciar nos saberes sobre o gênero e a sexualidade. Para Miskolci (idem) existe uma "nova visibilidade" que propicia uma mirada queer no Brasil, em decorrência de marcos específicos - a exemplo do fenômeno da (pós) SIDA, a parada gay de São Paulo, as mídias especializadas e o pink money. Segundo ele, a predominância de uma "onda política-acadêmica" voltada para a estratégia política da integração no pós-ditadura e a ideia exclusivista de nação são os principais obstáculos do queer no Brasil. Apesar disso, Miskolci (ibidem) aponta que os estudos queer brasileiros têm gerado um debate intenso nas políticas sexuais do país. 
Colling (2015) segue por outro caminho para analisar essa questão. Ao contrário de Miskolci (2015a), ele parece investir em outro tipo de abertura. Para ele, é preciso rebater a concepção que a perspectiva queer é uma formulação que tenta enquadrar os contextos brasileiros conforme seus moldes estrangeiros coloniais. Colling atenta para o fato da Teoria Queer não ter uma nacionalidade e uma origem pura em termos de regionalidade e episteme. Colling (2015) continua alertando para não esquecermos o pioneirismo de algumas iniciativas que já se mostravam, antes mesmo do queer, como enferentamentos rebeldes às normatividades de gênero e sexualidade. Para o pesquisador, é necessário trazer à tona o quanto já fomos queer sem nos dar conta desse fato. Colling (2015) acredita numa tática política atravessada pela micropolítica, que está vinculada numa transformação nas subjetividades. Ou seja, considerar que nem sempre as políticas que ocorrem no campo da macropolítica, por meio de marcos legais e autenticidades institucionais, são as mais interessantes na luta pelas diferenças sexuais e de gênero. $\mathrm{O}$ autor aponta para a potencialidade das artes (literatura e teatro) para embasar essa sua ideia. Ou seja, temos aqui duas diferentes posturas para pensar o queer no Brasil. Uma que reflete a partir de marcos macropolíticos e outra que aposta exatamente nas potencialidades de políticas mais autonômas, que pensam em especificidades e em enfrentamentos mais precisos.

Além desses últimos fatores que elenquei, também devemos analisar criticamente a própria geolocalização do conhecimento queer no Brasil. Penso que podemos imaginar esse fenômeno pelo menos a partir de dois fluxos: uma que dá "autoridade" sobre este assunto a algumas pessoas e outro que está relacionado a uma geografia dos espaços de legitimidade na construção de conhecimento no país. Obviamente que não quero estabelecer uma dicotomia regionalista, mas as evidências de uma diferença de abordagem no que tange o queer no Brasil são notáveis. Ademais confinar todas as pessoas da região Nordeste dentro de um núcleo vanguardista e as da região Sudeste-Sul dentro da égide de conservadoras é um grande equívoco. ${ }^{7}$

Na esteira das colonialidades, existe uma dinâmica interna em que a própria posição de subalternidade ao Sul Global pode ser relativizada

\footnotetext{
${ }^{7}$ No eixo Sudeste-Sul, destacaria, por exemplo, o trabalho do pesquisador Jorge Leite Jr., que traz reflexões sobre a possibilidade de nos tornarmos monstros, também construindo uma narrativa que burla os moldes acadêmicos. 
internamente. Quero dizer que o Brasil - mesmo estando numa posição de periferia - nutre relações outras que exclui e discrimina regiões que não estão localizadas no Sudeste-Sul do país, em estados como Rio de Janeiro e São Paulo. Basta observarmos a recorrência de grupos de pesquisa e pessoas teóricas que são chamadas e autorizadas a falar em espaços coletivos, entrevistas e pesquisas. Talvez um bom exemplo de insurgência a esse modelo é a realização do Seminário Internacional Desfazendo Gênero exclusivamente na região Nordeste. Uma iniciativa que visa discutir a crítica queer levando em consideração as potencialidades regionais e os locais ainda preteridos dentro da geolocalização da produção de gênero e sexualidade no Brasil. Uma resposta ácida, localizada e regionalizada à normatização e culto à produtividade numérica de grupos e pessoas pesquisadoras que pareciam durante muito tempo apontar para onde deveríamos olhar.

Definitivamente, a perspectiva queer vista daqui (Nordeste-emergentesubalternizado historicamente) é sensivelmente diferente daquela de lá (Sudeste-Sul-desenvolvido-elitizado). Os trópicos do Nordeste talvez tenham odor de dendê, suor e carne de charque. Seja mais ensolorado, mais orgiástico, menos branco e esteja sujo de mangue.

Essa percepção parte da própria forma como venho analisando encontros e produções que se debruçam sobre a perspectiva queer no Brasil. Numa análise que precisa ser aprofundada e melhor sistematizada, é possível identificar, por exemplo, como existe uma distinção de abordagens entre Nordeste e Sudeste-Sul. Mais uma vez tomarei como exemplo o Desfazendo Gênero e também o I Seminário Queer.

No livro de apresentação do I Seminário Desfazendo Gênero (14 a 16 de agosto de 2013), Berenice Bento e Antônio Vladimir Félix-Silva apontam a iniciativa do encontro como um ponto de inflexão que questiona a postura que muitos eventos queer trazem em seus formatos. Elas dizem:

Ao contrário dos outros eventos científicos nos quais a sisudez dá a tônica da seriedade do que é dito, típica performance da "comunidade acadêmica", no Desfazendo Gênero a alegria das cores, roupas, dos jeitos, dos trejeitos das/dos participantes avisava que o nosso encontro era viado, transviado, feliz" (BENTO; FELIX-SILVA, 2015, p. 5). 
O que é trazido nessa apresentação é como as vivências das pessoas, que antes eram tratadas como "objetos de pesquisa" ou que deveriam "manter a linha" para obter uma respeitabilidade acadêmica é implodida com a realização de um encontro que planeja adotar outra estratégia. “As margens intelectuais da universidade brasileira gritavam com suas performances intelectuais e existências: 'olha nós aqui. Veja como somos muitos. Admirem nossa exuberância. Contagiem-se com nossa alegria."” (idem), continuam. Chamam atenção ainda para o próprio caráter da riqueza das nossas narrativas na tessitura de políticas da estética, modos de fazer científico que estejam intimamente vinculados ao nosso mundo.

O evento, que teve a primeira edição em Natal, no Rio Grande do Norte, pareceu catalisar ainda mais esses ideais de transgredir a forma quando veio para Salvador em sua segunda realização (04 a 07 de setembro de 2015). Não só porque levou Judith Butler para a conferência de abertura, mas também por investir em performances, oficinas e palestras que traziam pessoas que não necessariamente estavam em consonância com as diretrizes da universidade. Basta lembrar o apelo da transativista Indianara Siqueira para que as pessoas aprendessem na universidade dos becos da rua. Sem contar nas performances, shows e na própria fechação que 1500 pessoas exalavam pelas ruas da velha Bahia.

Aliado a isso, uma série de pessoas pesquisadoras estão investindo em escritas que burlam a autoridade do cientifismo paralítico, a exemplo das produções do próprio grupo de pesquisa baiano CUS - do qual faço parte e que não para de parir pelos fundos uma sorte de subjetividades e pesquisas indisciplinadas que lambançam o status quo acadêmico. Citaria aqui, por exemplo, a dissertação de Fábio Fernandes (2014) e sua composição como bicha-Exu-flaneur pelas ruas de Salvador até o seu encontro com uma transformista num beco destinado ao público LGBT na cidade.

Uma outra linha, situada em outra geografia e com um modo de fazer mais tradicional, cito a realização do I Seminário Queer, promovido pela revista CULT, em São Paulo, nos dias 9 e 10 de setembro de 2015. Depois de realizado, o evento recebeu uma série de textos críticos na internet $^{8}$ que questionavam onde estava o "queer da questão" num

\footnotetext{
${ }^{8}$ Ver ARAÚJO, 2015; ATHAYDE, 2015; PRANDO, 2015. 
evento que tinha reiterado uma maneira engessada de discussão e de produção de conhecimento. As análises giravam em torno da ausência de pessoas trans na grade de programação, além da própria forma como o evento se configurava - através de falas de pessoas vinculadas a um ambiente universitário consagrado e, em sua maioria esmagadora, brancas. Um dos pontos comentados na web sobre esse evento era o veto a apresentação de uma drag queen convidada por uma das palestrantes (ARAÚJO, 2015).

O evento foi ironizado na internet como "Cisminário Queer" (ATHAYDE, 2015), numa referência à cisgeneridade de todas as pessoas que palestravam no seminário, além da exclusão das pessoas trans em sua grade. Três pessoas da plateia questionaram ao curador do evento, Richard Miskolci, por meio de perguntas escritas, o motivo da ausência de pessoas negras e trans no evento, além do motivo de pessoas pesquisadoras continuarem estudando esses grupos sem que eles discursem sobre si. Ele respondeu:

[...] não estou falando pelos outros, mas com os outros. Falar com é um posicionamento político, sobretudo, numa sociedade que nos joga sempre no enfrentamento, na violência, no conflito e nos divide - tirando de nós a nossa força, o nosso potencial político-intelectual. E é minha visão. No que toca falar pelo outro, penso na Spivak, vamos pegar Spivak, a ideia da Spivak é a seguinte: o subalterno não pode falar porque ele não tem voz. Você pode trazer às vezes as pessoas e dar o microfone para elas e falta vocabulário (MISKOLCI, 2015b).

Num dos textos críticos sobre o evento, a pesquisadora Athayde rebate essa afirmação de Richard, ao dizer:

Não quero aqui fazer a simples tarefa de personalizar a crítica de que o mundo acadêmico dá muito mais lugar para saberes hegemônicos. Ou seja, culpar apenas uma pessoa pela academia ser um espaço hegemônico. Enquanto pesquisadora, só consigo pensar que precisamos ocupar esses espaços acadêmicos. Porque não dá mais para aguentar homem cis, branco e de classe média achando que usar pessoas negras, trans, trabalhadoras sexuais como objeto de pesquisa é bacana, mas que não quer dividir espaço com essas pessoas. Não é necessário ter doutorado ou qualquer coisa que seja para produzir conhecimento. Os saberes produzidos pela militância são de extrema 
importância e fazem parte da construção da própria teoria (ATHAYDE, 2015, s/p).

Alinho-me ao que Athayde (2015) traz em seu texto, principalmente por identificar que não é através da criação de um vocabulário acadêmico que uma pessoa "não-letrada" contribuirá para as políticas de gênero e sexualidade numa perspectiva da diferença, mas sim, através das suas potencialidades específicas dentro dos seus contextos de conhecimento além universidade. Além da própria dimensão colonial da fala de Miskolci (2015b) com um ideal muito "paternalista" de que é preciso criar uma maneira específica para se falar aquilo que muitas pessoas já discursam de modo bastante diferente da universidade.

A partir disso, eu creio que é possível traçarmos linhas de fugas a essas formas de pensar o queer no Brasil. Aqui, os horizontes que enxergamos é de conversar com um cineasta do Nordeste, que ergueu sua estética no Nordeste e que tem uma sintonia com uma perspectica queer brasileira antes mesmo do surgimento dela do modo como conhecemos hoje. Não é bem dizer que os filmes de Jomard são queer. Isso seria anacrônico. Mas é perceber que outras políticas queer foram construídas à margem da margem e que aquela mais difundida por aqui ainda não prestou atenção suficientemente para outros tipos de sensibilidade e conhecimento.

\section{O grito gongadeiro de Jomard Muniz de Britto}

Com o avançar das leituras e da proximidade com Jomard, penso as produções do mau velhinho como uma política da diferença que articula outras maneiras de construir conhecimento. É através da imagem cinematográfica que JMB constrói suas narrativas mais provocativas. $\mathrm{O}$ primeiro filme que me fez despertar para o universo poético do mau velhinho, no que tange os gêneros e às sexualidades, foi "Maria Aparecida no carnaval". O filme, de 1974, é resultado de uma relação extensa entre JMB e Maria Aparecida. Essa que era, segundo o autor conta no filme, chamada ora de Mário, ora de Maria Aparecida. O segundo nome vem da participação dela durante o carnaval, quando se vestia de forma extravagante em trajes convencionados como femininos. O filme, rodado em super-8, é um registro do candomblé na década de 1970 no Recife, contado sob a ótica de Maria Aparecida. 
Nesse sentido, me parece que essa obra não necessariamente seja um documentário, mas um trabalho em que JMB compõe, junto à Maria Aparecida, as cenas que dão corpo ao filme.

"Professor, quando nasci, já nasci dentro do azeite", diz Maria Aparecida descendo em ritmo cadenciado uma escadaria, calçando um tamanco enfeitado com acessórios brilhantes, calça boca de sino e uma bata estampada. Sua nação do candomblé era o Congo e ela adverte para a complicação de praticar candomblé em decorrência da repressão policial às religiões afro-brasileiras. Aos 7 anos, descobriu que seu orixá de frente era Oxum e, por uma suposta incompatibilidade de gênero, a mãe de santo que cuidara dela queria mudar o seu orixá para Xangô. "Porque Oxum era um orixá feminino e ficava muito feio para mim porque eu era masculino. Mas, eu quero aquilo que a natureza me deu. Eu quero aquilo que Deus me concedeu".

Figura 1 - Frames de "Maria Aparecida no carnaval" 


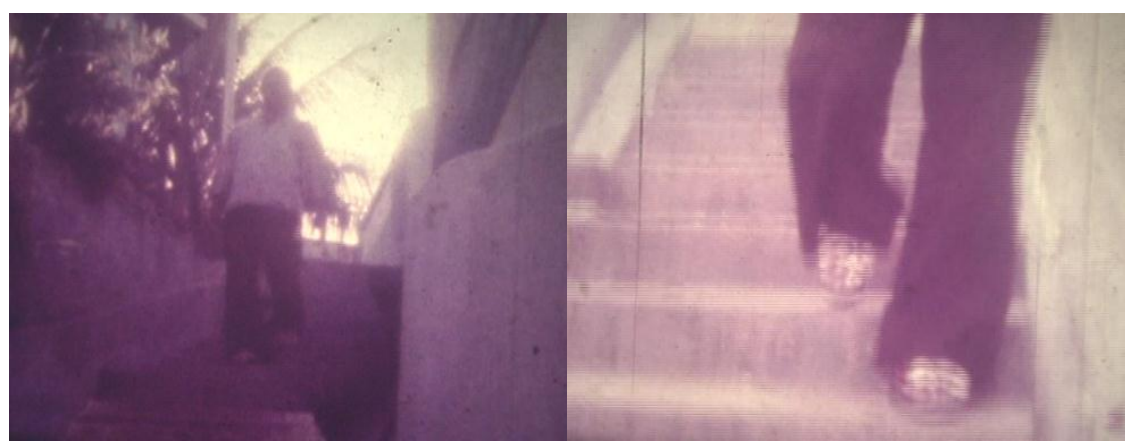

As imagens que cobrem a voz-off de Maria Aparecida retratam detalhes do Palácio de Oxum - terreiro onde ela é zeladora. Uma sereia pintada na parede surge na tela, intercalada com o registro de um mar calmo que se estende vagarosamente por um infinito horizonte. Oxóssi com uma espingarda abre espaço para o letreiro do Palácio: "Consultas diárias sobre a responsabilidade do babalorixá Mario Miranda".

Figura 2 - Frames de "Maria Aparecida no carnaval"

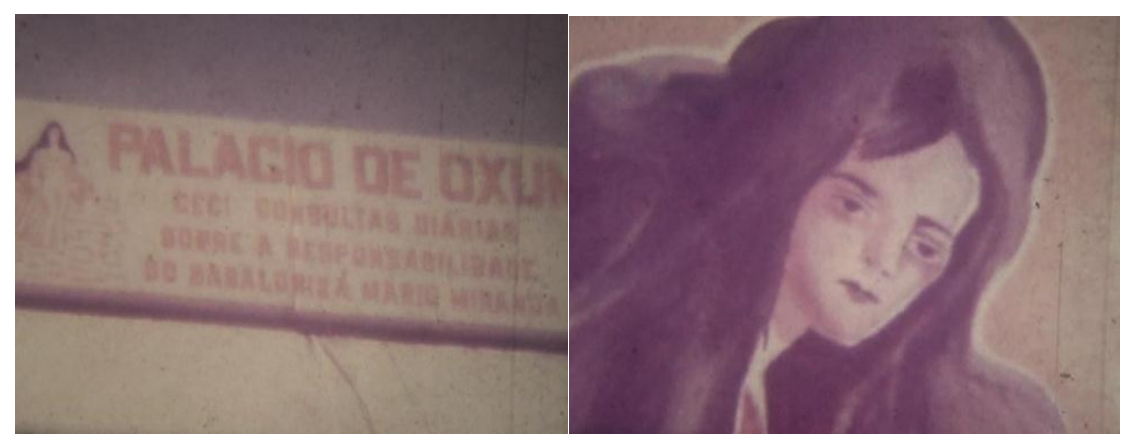

Maria Aparecida encara a câmera ao lado de uma escultura vermelhoExu, ornado com um tridente e uma coroa cravejada de pedrarias.

Tem muita gente que diz: - Ah, eu não sei. Mário não é feito. Mário nunca foi feito. Mas, eu tenho os meus antepassados. Agora eu não vou dizer a ninguém porque não interessa. Eu estou dizendo ao professor Jomard de Britto, que é uma pessoa de minha inteira confiança. 
Maria posa para a câmera num mirante. Seu olhar passeia na paisagem. A câmera a enquadra dos pés a cabeça, revelando suas unhas pintadas de branco e seus cabelos presos para trás. A cena que segue a revela em frente a um espelho penteando seus cabelos soltos com o cumprimento pouco acima dos ombros. "O pessoal me chama de Mário, outros de Maria Aparecida e eu gosto muito de carnaval". Uma fotografia na parede, filmada em close, mostra Maria ao lado de uma figura de sereia trajando um longo e volumoso vestido, adornada com uma coroa brilhante.

Figura 3 - Frames de "Maria Aparecida no carnaval"

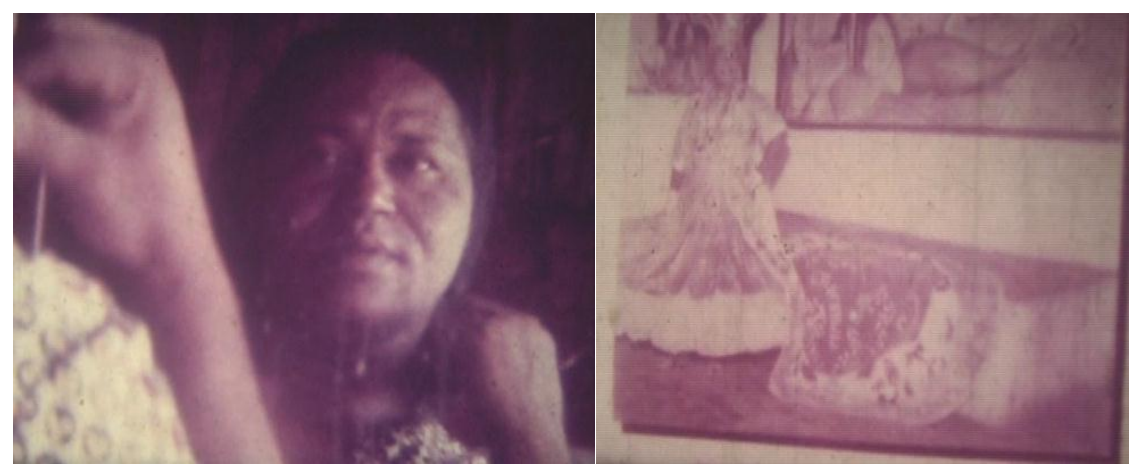

As pessoas esperam sentadas no salão do terreiro. Ao fundo, alabês, responsáveis por tocar os sons dos atabaques e entoar os cântigos ancestrais. Um altar com iconografias de santos católicos e representações de orixás abrem espaço para Maria Aparecida jogar os búzios frente à câmera. Nessa passagem, possui um bigode, traja bata estampada e um turbante vermelho. A festa começa. Filhos, filhas de santo e demais pessoas frequentadoras do Palácio ficam de pé no barracão. O lugar é tomado por uma fumaça espessa vinda de um defumador. "É um defumador de purificação. Que tira a quizila das pessoas que estejam com mau espírito, encosto ruim. Então a gente faz aquela prece, dá aquele defumador e serve para todo mundo que está ali naquela comunhão". Os alabês começam a dar passagem aos sons que evocam as forças ancestrais. Todas as pessoas cantam em coro. $\mathrm{O}$ som ritmado é acompanhado por Maria Aparecida e outras integrantes da casa de santo. $\mathrm{O}$ xirê, roda em que as pessoas do terreiro dançam para 
saudar os orixás, é iniciado. Maria está no centro da cena, toda trajada de vermelho e branco.

Essa última festa de São Jorge foi muito boa porque eu gosto de sempre fazer a festa de São Jorge por ele ser protetor dos militares, aqui vem sempre muitos militares. Infelizmente só tem uma coisa que eu me sinto mal porque o pessoal aqui não deixa ninguém soltar fogos. Nem agora na época de São João mesmo. Eu comprei uns fogozinhos pro meu garoto soltar, então, os vizinhos impede da gente soltar fogos, não sei porque. Em todo canto as pessoas soltam fogos e ninguém proíbe. Mas aqui sempre que a gente solta fogos aparecem os vizinhos dizendo que vai dar parte. A polícia manda chamar. Não sei porque. O sol nasce para todos, mas para mim falta um pedaço

Figura 4 - Frames de "Maria Aparecida no carnaval"

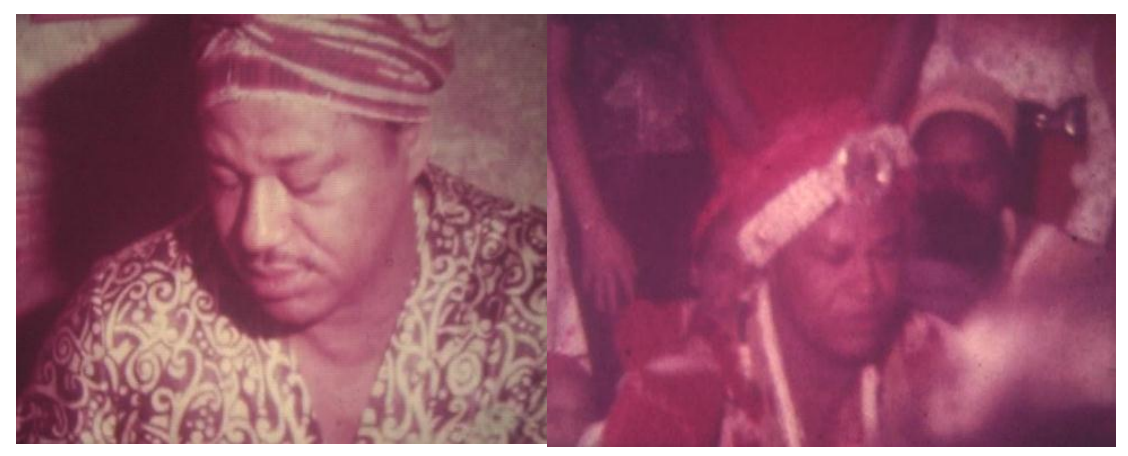

Filhas de santo de Maria Aparecida pedem à benção para ela em sinal de reverência à sua autoridade espiritual. Crianças e adultos acompanham a festa. Maria surge sorrindo e cantando. Atabaques e agogô continuam dando o ritmo para a adoração aos orixás. Turbantes, anáguas, guias, contas e amuletos protetores protegem e revelam os pertencimentos das filhas e filhos de santo. Uma bandeira do Brasil surge na tela e abre espaço para uma entidade que traja armadura e um capacete prateado.

Figura 5 - Frames de "Maria Aparecida no carnaval" 


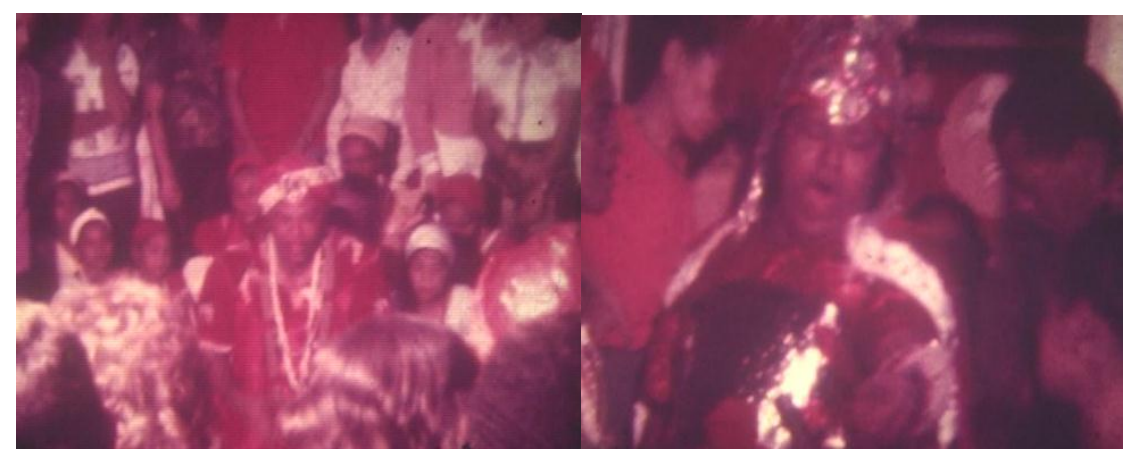

O clima sagrado é totalmente interrompido com o registro de uma fotografia de Maria Aparecida vestida no carnaval. Logo abaixo deste, um retrato de Getúlio Vargas está preso à parede. Na bancada, uma foto de Maria Aparecida de cabelos soltos, ladeada com um altar composto por figuras da Igreja Católica e do Candomblé. Maria surge sorridente e radiante com um vestido brilhante e pomposo. Suas contas de orixá fazem par com pulseiras, turbante, brincos grandes, batom vermelho e sobrancelhas pretas arqueadas. Aparecida treme os ombros e performa para a câmera, que é agraciada, ainda, com um beijo. A mão é quebrada de forma ritmada para um close.

Figura 6 - Frames de "Maria Aparecida no carnaval" 


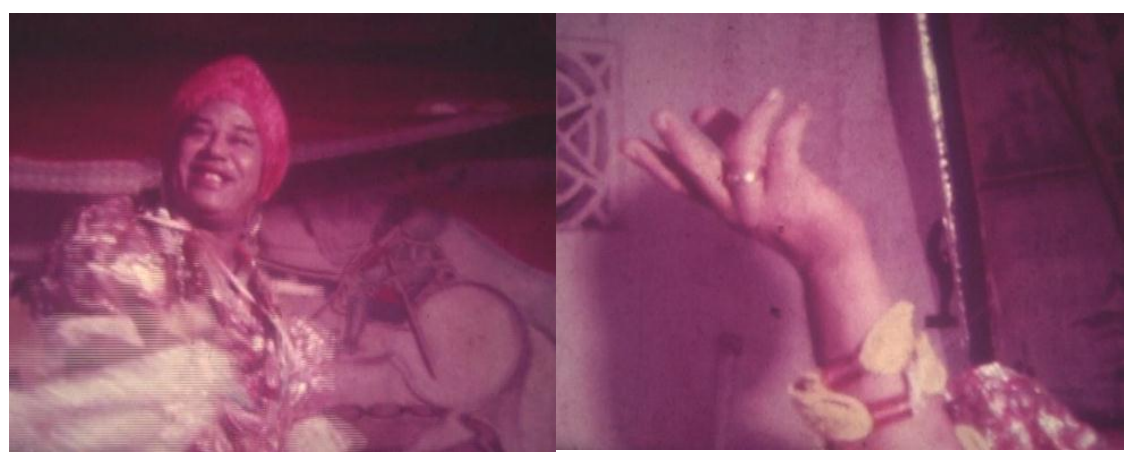

"Me traz uma grande tristeza em saber que a minha noiva não é foliã, não gosta de carnaval. Então, não sei como vai ser na passarela. O público esperando Maria Aparecida. Porque quando eu chego ali o pessoal me cobre de êxito, de palmas, me aplaude. $O$ prefeito me aplaude. Aquilo para mim é uma glória. E ela diz que não gosta de carnaval. E eu não sei como é que vai ser. Mas, eu vou fazer um carinhozinho para ela bem direito. Porque ela sabe que eu estou de saia, mas não vai tirar nada da minha masculinidade. Eu sou o mesmo homem. Eu estou ali de saia, mas por baixo eu estou de calça". Maria Aparecida continua sua dança para a câmera, tremendo os ombros, retocando sua maquiagem. Já é carnaval e Aparecida dança. Abaixo de uma pintura de sereia na parede, Maria Aparecida posa para câmera como se fosse uma também e se despede com as mãos arqueadas como num passo de dança. Seguem os créditos escritos pelo próprio JMB nas areias de uma praia do Recife. 
Figura 7 - Frames de "Maria Aparecida no carnaval"

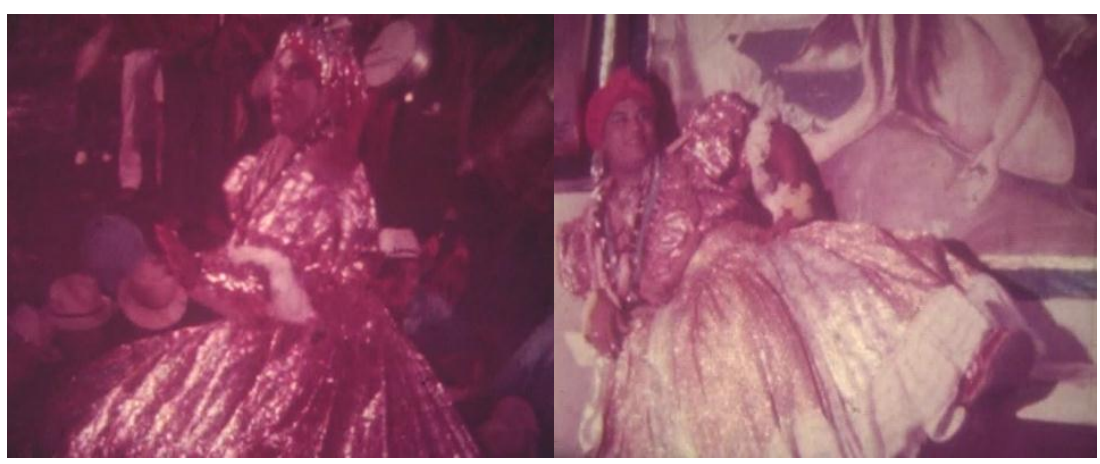

Para começar a tecer uma análise mais relacionada com as conversas sobre a possível genealogia das políticas da diferença no que tange as dissidências sexuais e de gênero no Brasil, realizarei uma série de pontuações que auxiliam na compreensão dos contextos de realização das obras de JMB. Tentarei perpetrar o mesmo trajeto que realizei no decorrer da pesquisa, a partir da entrevista com JMB e também de suas indicações, para depois então realizar um trabalho mais relacional com tudo que já discuti anteriormente.

Em um dos meus encontros com Jomard eu pedi para que ele comentasse sobre esse filme. Pergunto por que JMB trata Maria Aparecida como Mário nas conversas e de que forma ela encarava esse tipo de tratamento. Também indaguei porque Maria Aparecida diz que tem inteira confiança nele. Talvez a primeira resposta já esteja no próprio filme, já que Maria Aparecida, dentro dos contextos do sagrado, é tratada como "Babalorixá Mário Miranda”, uma autoidentificação.

No filme eu quero colocar justamente essa dualidade, que para Mário não era dualidade. Ele era tudo isso ao mesmo tempo agora. Ser pai de santo, se vestir como homem, que se vestia com roupas de mulher para o carnaval. E com o tempo ele ficou sendo somente Maria Aparecida mesmo (BRITTO, entrevista, 2014).

Então, é a partir da própria transitoriedade de suas identificações que devemos nos aproximar de Maria Aparecida. A relação de JMB e Maria se dá a partir de uma continuidade percebida no filme pela maneira 
como a presença dela se apresenta: em alguns momentos com pelos faciais, em outros com roupas mais convencionadas como femininas e adereços leves, em outras cenas com trajes brilhantes de festa e com maquiagem pesada. Portanto, a relação de confiança entre ambas se dá através do próprio processo de contato antes e durante a feitura do filme. Além, obviamente, da posição de JMB enquanto um professor - que talvez lhe conferiria alguma legitimidade - e também defensor das diferenças como contenda política num tempo de forte repressão às dissidências.

Jomard me diz que conheceu Maria Aparecida por meio de Roberto Mota, um professor antropólogo que já havia feito uma série de entrevistas com ela. Eu questiono sobre uma memória específica que tenha sobre Maria e ele diz que anualmente ela realizava uma grande festa em comemoração ao seu aniversário. Ela recebia todas as pessoas com trajes mais próximos aos de pai de santo. Quando era perto de meia noite, ela se recolhia e depois surgia vestida de debutante para dançar com todos os homens que estavam no local. "Era uma festa com muito luxo e comida. O público era muito eclético” (idem).

Eu questiono JMB sobre qual a relação que Maria Aparecida tinha com a mulher que ela cita no filme. Ele responde que não entendeu muito o motivo, mas que houve o casamento e foi à cerimônia. Segundo ele, Maria tinha revelado que a mulher tinha insistido muito, que gostava dela e então decidiram realizar o matrimônio dentro das tradições do candomblé. "Primeiro, ele não era rico e nem coisa nenhuma. Ela queria mesmo era ficar junto dele." Jomard sorri e diz que acha que o casamento não durou um mês.

A conversa continuou na sala do apartamento do mau velhinho no Centro do Recife, entre livros, cds, pôsteres de filmes e fotografias. Começamos a falar sobre Ditadura Militar e como existia uma repressão às pessoas que burlavam as normas de gênero. Questionei sobre como Maria Aparecida se configurava nesse contexto, já que ela cita no filme que gosta de fazer a festa de São Jorge em decorrência da vinculação do santo com os militares.

Mário Miranda, eu acho que ele não causava nenhum problema para a ditadura. Nem a ditadura para ele. Porque primeiro ele era famoso como homossexual e ele era muito valente. Se alguém xingava ele, ele ia para os murros, os tapas (BRITTO, 2014, entrevista). 
Em seguida JMB me conta que certo dia saiu no jornal que Maria havia sido agredida e todos os políticos e autoridades foram visitá-la no hospital. "Eu estava com um bofe. E eu achei que o camarada estava fazendo uma massagem em minhas costas, mas era uma faca! Ele me disse, imagine". Em seguida, conversamos sobre a repercussão do filme dentro dos circuitos de cinema e o mau velhinho defende que a ditadura estava mais vinculada à uma repressão sexual do que necessariamente militar.

Amigos meus diziam, "mas Jomard como você um intelectual faz um filme sobre uma bicha?" Me pediam para explicar. A ditadura era mais sexológica do que política. $\mathrm{E}$ eu respondi para ele que não tinha nada a explicar para ele. Sinal de que realmente eu não tinha aderência a esse tipo de pensamento (BRITTO, 2014, entrevista).

Outro fator que o mau velhinho aponta para identificar essa ditadura mais sexológica do que política é quando foi hostilizado ao lançar o Manifesto Tropicalista que trazia em uma de suas linhas a ordem "O sexo contra os dogmas". As pessoas se indignavam porque imaginavam que isso estava intimamente relacionado com o dogma da Igreja. Em alguns casos vaias foram proferidas quando da leitura do manifesto. Jomard ressalta que quando se refere a dogmas não está citando necessariamente uma linha clerical. Dogma ali estava relacionado a uma série de posturas que engessavam os modos de vida das pessoas dentro do que chamava de "feudalismo cultural".

Ainda recorrendo a esse último fato, é importante situar como Jomard, mesmo dentro de uma vanguarda artística, ocupa uma posição de dissidência. Isso porque ele insiste na posição de abjeção como uma tática para compor o seu universo poético. De tal modo, ainda que haja nos seus processos um alinhamento com a Tropicália e o Cinema Novo, existe um diferencial que reside no desejo de JMB em estar junto de pessoas que são rechaçadas pela sociedade (mesmo por aquele grupo que seria de vanguarda). Quando Jomard é questionado o porquê de um intelectual como ele fazer um filme sobre uma "bicha", a premissa é que ele deveria canalizar sua atenção para pessoas e questões que fossem "mais importantes". "Maria Aparecida no carnaval" está preocupado, portanto, em contestar a existência de subjetividades que surgem a partir de enfrentamentos identitários que poderiam ser, inclusive, tomados como contraditórios. 
A controvérsia sobre a intolerância religiosa também é um ponto forte no filme. A preocupação de JMB, nesse sentido, não está somente numa vinculação com a individualidade de Maria Aparecida. A partir dela, o filme consegue discutir como as pessoas praticantes de religiões afrobrasileiras sofreram historicamente com a interdição de seus cultos e a dúvida sobre a legitimidade de sua fé. Maria Aparecida tem consciência de sua posição de subalternização dentro dos processos sociais daquele período, contudo, o filme trata de revelar como há um gozo performático e performativo dessa posição que ela ocupa. Aqui parece haver outra grande potência para pensar em políticas da diferença que não desejam uma inclusão social a qualquer custo. Maria Aparecida, mesmo sofrendo com a intolerância religiosa e as consequências da heteronormatividade/cisnormatividade, nos informa que é na resistência cultural e nas potencialidades corporais que poderemos construir uma perspectiva que glorifica as diferenças.

Durante o processo de análise dos filmes, uma das reflexões que mais surgiam era se Jomard, na condição de homem e que goza de uma posição de privilégio intelectual, não estaria praticando um tipo de cinema exotificador, que explora identidades desviantes para construir o seu universo artístico. Quem me deu a resposta foi Maria Aparecida e ela apontou que não. Maria constrói a própria maneira como ela deseja ser narrada no filme. Nenhuma das suas aparições são ingênuas. $O$ filme é uma construção coletiva de quem dirige e de quem performa para a câmera. A hierarquia entre realizador e pessoa cinematografada é dissolvida na medida em que Maria Aparecida constrói a própria cena em que ela está inserida. Assim como JMB não se deixa biografar, Maria Aparecida, frase a frase, pinta a pinta, burla os mapas de significado que a audiência poderia inferir sobre ela.

Judith Butler puxa um tamborete no boteco e toma um copo de rum em companhia de Jomard na medida em que as narrativas em torno de Maria Aparecida evidenciam como o gênero é construído por meio de paródias, através de processos ficcionais. Ao performar uma corporificação inspirada em Carmem Miranda, Maria constrói para si um gênero que é reiterado por meio de uma cópia, uma pirataria de gênero que desloca as noções disso como um dado natural. Nas palavras da própria Butler, o gênero é "a estilização repetida do corpo, um conjunto de atos repetidos no interior de uma estrutura reguladora altamente rígida, a qual se cristaliza no tempo para produzir a aparência de uma substância, de uma classe natural de ser" (BUTLER, 2003, p. 
59). Butler, Jomard e Aparecida parecem seguir conversando no que tange a desestabilização da linha sexo/gênero/desejo/prática sexual. Apesar de todo ideal coercitivo para que as pessoas sigam essa linha de forma coerente, existem processos de subjetivação que fogem à essa normatividade e desestabilizam os modelos de sexualidade e gênero. É o caso de Maria Aparecida. A própria transitoriedade do seu corpo e as performatividades de gênero, que ora se apresenta como Mário Miranda e ora como Maria, nos municia para afirmar que o sexo com o qual nascemos não deve ser tomado como única referência para aprisionar o gênero, as práticas e os desejos sexuais. No momento do filme, Maria Aparecida é casada com uma mulher e diz que o fato de vestir saia não compromete sua "masculinidade". Já em entrevista dada a Jomard e João Silvério Trevisan (2002), Maria Aparecida se considera como "transvesti”, tem desejo e pratica sexo com homens. Ou seja, a própria existência dela traz consigo que os corpos nunca estão conformados às normas, tal qual afirmou Butler (2003). Ademais, a própria ideia de masculinidade se vê fissurada, exibindo que as masculinidades não são puras e centradas tal qual propagam os baluartes da heteronormatividade. Definitivamente, o que está em jogo neste caso específico é uma implosão desconstrutiva das verdades sobre o sexo e o gênero, é uma aposta artística que narra uma possibilidade de escape e com isso põe a bala no canhão para o alastrar de outras subjetividades.

Nessa linha podemos imaginar que se Butler, em "Problemas de gênero" (2003) toma como referencial as bichas negras do filme "Paris in burning" para refletir sobre performatividade de gênero, JMB e Maria Aparecida fazem um bordejo parecido, no entanto, mais carnavalizado e mais afrobrasileiro. Ter consciência desse duplo processo é, então, uma etapa fundamental para deslocar o queer dos seus locais de criação "oficial", aproveitando do seu melhor, intercambiando experiências e conhecimentos construídos desde aqui e passando por um processo de intensa e intermitente decolonização.

É impossível assistir esse filme e não pensar como ele é construído de maneira interseccional. Basicamente, a ideia de interseccionalidade parte da tentativa de perceber como dados sociais e identitários se influenciam mutuamente numa cruzada para conformar os corpos como as questões de raça, gênero, sexualidade, classe e geração. $\mathrm{Ou}$ seja, não é possível que os diferentes pertencimentos sejam analisados de maneira pura ou separadas. Esse ideal dos atravessamentos 
identitários também são traços fundamentais para pensar como as políticas de diferença são erigidas. $O$ conceito de interseccionalidade surge com maior força na segunda onda do feminismo, graças às contribuições das feministas negras que criticavam duramente como essa corrente política encontrava-se branca e com ideias eurocêntricas. Kimberle Crenshaw (1991) escreveu um artigo seminal para essa questão ao discutir a necessidade de uma estratégia antirracista dentro da luta feminista. Assim, os marcadores de raça, gênero, sexualidade e religiosidade são relevantes para o entendimento das narrativas que discorrem da película "Maria Aparecida no carnaval". Pensando de maneira relacional podemos perceber como ela (a personagem) também é resultado dessas inscrições da diferença sobre seu corpo.

Outro fator que segue neste mesmo fluxo é o fato do filme acompanhar Maria Aparecida em diversos locais identitários, explorando as posições que ela ocupa nesses espaços. Maria é babalorixá, é a dançarina de maracatu, é a transvesti que segue descalça para Olinda. O trânsito dos cenários do filme acompanha também os diferentes estados de conformação e estilização do seu corpo - que se apresenta distintamente em cada espaço de convivência social. Maria Aparecida constrói sua existência a partir de acessórios e vestimentas que são convencionadas como sendo do universo feminino e

[...] se por um lado, a articulacão vestimentar dá conta de uma dimensão formal, ou seja, age através das determinacões sociais, sexuais, etc., por outro lado, ela reafirma sua dimensão formante, nos oferecendo, assim, um perfil sensível e metafórico de uma trajetória pessoal, estilizando-a num personagem social, inscrito numa ambiência particular (CIDREIRA, 2005, p. 136) (destaque da autora).

Quando levamos em consideração os recursos técnicos do cinema que são explorados no filme temos uma observação complementar a essa. A predileção da câmera em percorrer todo o corpo de Maria Aparecida (como em planos que iniciam nos pés e vão até o rosto ou o close em partes do corpo que estão enfeitadas com acessórios e maquiagem) é utilizada para este fim: colocar uma lente de aumento para a maneira como Maria Aparecida estetiza o seu gênero em trânsito. Também há uma tendência em filmar com plano fechado os detalhes dos locais em que se decorrerão as cenas. Imagens sacras, fotografias, pinturas, joias, contas de orixás, atabaques e até o letreiro do Palácio de Oxum são 
filmados com o intuito de situar esses locais de pertencimento de Aparecida.

Outra pauta a ser considerada é no que tange as incorporações de entidades do candomblé/umbanda e os papéis de gênero que são atribuídos a elas. O candomblé é uma religião de matriz africana que, quando da sua chegada no Brasil, sofreu processos de ressignificação dado o contato com outros povos e também da proibição por parte dos colonizadores europeus. O culto do candomblé traz como elemento principal a valorização das forças da natureza como uma forma de adoração aos ancestrais. A religião se espalhou pelo Brasil e se diferencia através de dispositivos que acionam a ideia de "nações", diversificando as formas de culto (BASTIDE, 2001). O candomblé, exatamente por seu caráter migratório e pela coerção que sofria (e ainda sofre), encontrou estrategicamente uma maneira de se propagar: por meio de associações relacionais com o Catolicismo, ao que se convencionou chamar de sincretismo religioso. No candomblé orixás e pessoas filhas-de-santo possuem uma conexão a partir de seus enredos míticos, assim existem entidades que são generificadas como pertencentes ao masculino, ao feminino ou mesmo aos dois gêneros. Algumas dessas pessoas são "escolhidas" por destino ancestral para serem conectoras entre a terra e o mundo dos orixás através da experiência da possessão. A possesão é um momento esperado por todas as pessoas, já que é quando o orixá se corporifica na terra e que é desempenhada uma "performance" com danças, roupas e cânticos específicos de cada entidade. Nesse sentido, a possessão é um ponto relevante para entender as distinções de gênero dentro dos cultos afrobrasileiros - já que não necessariamente a pessoa que recebe o orixá está em consonância com o "gênero" do orixá que lhe tem como filho/a.

As religiões afrobrasileiras são conhecidas amplamente por acolher pessoas não-heterossexuais e trans. $\mathrm{O}$ pesquisador Ralph Mesquita (2004) aponta que existe um imaginário que vincula o candomblé a um local de aceitação das dissidências e, além disso, seria um espaço em que as potencialidades criativas das pessoas são valorizadas. Acrescentaria a isso o fato de não existir a noção de pecado cristão, que imputaria as pessoas uma exclusão por suas sexualidades e gêneros nãonormativos. Apesar disso, é recorrente a máxima de que homens que tem seu orixá principal "feminino" são homossexuais e mulheres que tem orixás "masculinos" são lésbicas. 
Embora ninguém confirme a possibilidade de uma identificação plena ou absoluta entre pessoa e orixá, muitos sacerdotes preocupam-se com o poder da saia. Receiam que os orixás possam interferir na sexualidade de seus filhos homens. Temem a homossexualidade masculina e seus possíveis efeitos visíveis na sociedade civil (preconceito, estigma, discriminacão etc.). [...] Ao que parece, a interferencia do orixá sobre a sexualidade do seu filho, caso exista, não é determinada religiosamente. (SANTOS, 2008, p. 6) (destaque do autor).

Assim que, ao tomarmos o filme como uma construção de conhecimento sobre esse universo, se por um lado Maria Aparecida rejeita ter o seu santo "trocado" para um orixá masculino (Xangô), que estaria em conformidade com o seu "sexo" (entendido aqui como materialidade do corpo), ela também reitera certo modelo heteronormativo que atribui sempre a homossexuais e pessoas trans orixás que são discordantes do seu sexo "de nascimento". Dentro do campo religioso, portanto, os processos que tangenciam os gêneros e as sexualidades são muito mais complexos do que a adoção de padrões por arquétipos e performatividades de gênero.

Todos esses esquemas levantados anteriormente levam à conclusão que "Maria Aparecida no carnaval" é uma potente construção de conhecimento para discutir de maneira não-normativa e pensar as complexidades identitárias através das políticas da diferença. Ao relegar o status quo, JMB traz no filme um conjunto de discussões que no momento de produção era considerado fútil ou não engajado. Exatamente por fugir de um tipo de engajamento predominante naquele momento que esta película mostra sua face mais provocativa: a dissidência dentro de um cenário que era considerado "marginal". Esse fator é interessante de ser aventado porque nos conduz a ideia de que, para além de fazer um cinema marginal, JMB produz um cinema sintonizado com uma polítização do abjeto. A própria abjeção do cineasta e também das pessoas com quem ele trabalha é o catalisador do caráter político insurgente de seus filmes.

Quando analisada conjuntamente, a obra de Jomard Muniz de Britto se desenha como um genuíno exercício, filme após filme, de achincalhamento da norma ${ }^{9}$. A mesma experiência de vergonha e de

\footnotetext{
${ }^{9}$ Para uma análise mais aprofundada e de diversos trabalhos da obra de Jomard, sugiro a leitura da minha dissertação (SANT'ANA, 2016). 
dedos apontados para os corpos violentados diariamente é devolvida para as normatividades por meio de uma força criativa movida, sobretudo, pelas diferenças sexuais e de gênero. $\mathrm{O}$ discurso cinematográfico de JMB está calcado em alguns elementos que são caros para o que hoje chamamos como perspectiva queer. Através de um registro mais prático que identificaria um prelúdio do queer no cinema jomardiano eu assinalaria algumas características que apontarei a seguir.

\section{Para além de uma conclusão}

1 - O filme de JMB apresentado aqui salienta uma desconstrução dos essencialismos identitários através de uma mirada interseccional sobre a realidade. É através de uma desestabilização dos papéis de gênero que a obra do mau velhinho opera nesse sentido. Maria Aparecida reivindica para si uma identidade de transveti e um lugar de fala como babalorixá e negra. A própria ideia de uma pessoa que flerta com o gênero feminino e se define como um sacerdote masculino, dentro de contextos específicos religiosos, já consiste num ponto de inflexão que pula as cercas da representação dentro de modelos de identidades fixos. Por ser um dos primeiros filmes de JMB, "Maria Aparecida no carnaval" é uma espécie de arauto do que há por vir na obra do cineasta: um disparar de corpos que fervem nas e através das diferenças.

2 - Os binarismos de gêneros são performativamente e performaticamente implodidos pelas composições artísticas jomardianas. Os discursos biológicos e patologizantes sobre os corpos são burlados na medida em que o cineasta incentiva a exibição de nossas diferenças dentro de contextos culturais e artísticos. Pernalonga em "Outras cenas da vida brasileira", outro de seus filmes ${ }^{10}$, performa seu gênero inconforme e dá a voz a um texto que questiona as próprias estruturas coloniais advindas de um "feudalismo cultural". Consciente de sua condição de não-normatividade de gênero, negra e pobre, Perna não possui a paralisia da culpa, mas ocupa os espaços públicos com suas

\footnotetext{
${ }^{10}$ A obra é uma espécie de tratado sobre a colonialidade no Brasil. Através de um discurso ferino e antinormativo defendido pela voz de Perna, JMB mais uma vez trata de pensar nos enfrentamentos identitários como formas de compor uma política que tentava revolucionar as estruturas sociais da época. Outras cenas segue sendo um filme que serve como parâmetro crítico para analisar a realidade brasileira. 
performances, exibindo a sua existência incomum e jogando o leite mal na cara dos caretas. Nesse sentido, a performance enquanto linguagem artística está intimimamente ligada a maneira como ela reitera seu gênero e sua sexualidade. Há uma estetização do trânsito, que longe de ser um espetáculo para causar o divertimento de uma audiência heteronormativa, implode a norma e critica, inclusive, as formas de fazer arte (defendendo a arte transformista).

3 - Existe uma crítica incessante às formas de normatização dos corpos e dos desejos, através de uma ironia e de uma perversidade que são imprescindíveis quando se fala de uma perspectiva insurgente e antissistêmica. Jomard põe a prova uma pedagogia funcionalista dos nossos corpos, subvertendo o seu uso tal como nos é sugerido pelas normatividades de gênero. As presenças nuas, negras, viadas, travestis nos filmes de JMB se associam para o estabelecimento de uma arte que mete o dedo em questões caras para a época - como os projetos de cidadania, os modelos de política regional e o próprio modo como se operava o cinema. As diferenças de gênero e sexualidade são a principal guerrilha contra as normatividades, cinevivendo suas existências como escapes e armadilhas aos sistemas coercitivos em plena Ditadura Militar.

4 - Existe uma politização da abjeção através do gozo do escracho e da esculhambação vivencial. O chiste e a ironia são recorrentes para rir da condição de subalternização ou para mostrar o quão ridículas são as normatividades - como, por exemplo, no filme "Vivencial I" 11 , quando um grupo de bichas profana os símbolos da Igreja Católica, associandoos a uma viadagem libertadora e ao pecado do desejo. Quando analisados conjuntamente, os filmes de Jomard reúnem pessoas que eram rejeitadas socialmente por suas condições sexuais, de gênero, raciais e sociais. Sua predilação por ter consigo esse grupo não é vã. Acredito que os filmes de JMB constroem uma política da dissidência sexual sintonizada com o que viria a ser conhecido como queer. As pessoas que compõem seus filmes não reivindicam para si um modelo representacional fixo, mas glorificam o trânsito e as transas como

\footnotetext{
11 Vivencial I é um filme-performance de 1974 protagonizado pelo grupo de teatro pernambucano Vivencial Diversiones. O filme se torna um marco para entender a atmosfera transgressiva do grupo na década de 1970. O filme traz como eixo principal as performances do grupo que expõe toda uma veia anti-clerical, ainda que em seu início tenha sido dentro da Igreja Católica.
} 
estratégia de combate às opressões.

Ao longo dessa investigação, tentei identificar como existe uma política que segue às margens dos processos mais tradicionais de ativismo e conhecimento, sobretudo aqueles denominados de queer. Aliás, é bom pontuar como conhecimento e ativismo são dois pontos que estão em alinhamento e geram uma combustão mútua. Essa fuga da escola do mainstream é possível de ser vista nos filmes de JMB, revelando a existência de um material riquíssimo que foi esquecido para se pensar em nossas políticas queer no Brasil.

Aliás, se há falha quanto a eficácia das políticas de gênero e sexualidade que vem sendo erigidas no Brasil nas últimas décadas, eu imagino que um dos erros seja o excesso de institucionalização e a crença de que existem meios legítimos de se constituir um ativismo apenas. A forma como JMB e suas comparsas constroem seus filmes e, consequentemente, seus conhecimentos, merece ser reconhecida como iniciativa que revela uma fenda produtiva de outros ativismos no combate às opressões de gênero e sexualidade a partir de uma perspectiva queer.

Outra questão que tem relevância a ser citada, para finalizar, é que existem arquivos nos diversos confins do Brasil que põem em questão a geolocalização dos ativismos de gênero e sexualidade no nosso país numa perspectiva dissidente/queer. Esses arquivos podem consistir numa "terceira margem do rio", no sentido de apontar para outros universos pouco visitados pelas historiografias. É através desses arquivos, como os de JMB, que será possível descentralizar de maneira mais radical uma narrativa oficializante sobre a perspectiva queer no Brasil, pois neles estão guardadas narrativas que - por seu caráter pouco vinculado a uma linguagem acadêmica ou que seja mais facilmente identificado por esse universo - podem nos dar outras pistas sobre a nossa própria história de ativismo. 


\section{Referências}

ARAÚJO, Eduardo. Cisminário Queer. Set. De 2015. Disponível em http://acoisatoda.com/2015/09/12/cisminario-queer/. Acessado em 9 de janeiro de 2016.

ATHAYDE, Thayz. I Seminário Queer e saberes subalternos. Set. de 2015. Disponível em http://blogueirasfeministas.com/2015/09/iseminario-queer-e-os-saberes-subalternos/. Acessado em 9 de janeiro de 2016.

BASTIDE, Roger. O Candomblé da Bahia: rito nagô. São Paulo: companhia das Letras, 2001.

BENETTI, Fernando José. A bicha louca está fervendo: uma reflexão sobre a emergência da Teoria Queer no Brasil (1980-2013). Trabalho de Conclusão de curso apresentado ao curso de História do Centro de Ciências Humanas e da Educação, na Universidade do Estado de Santa Catarina. 2013.

BENTO, Berinice; FÉLIX-SILVA, Antônio Vladimir. Apresentação. In. BENTO, Berenice; FELIX-SILVA, Antônio Vladimir. (orgs.). Desfazendo Gênero: subjetividade, cidadania, transfeminismo. Natal: EDUFRN, 2015. p. 5-9

BRITTO, Jomard Muniz de. Entrevista de Jomard Muniz de Britto concedida a Tiago Sant'Ana. 16 de julho de 2014, Recife.

BUTLER, Judith. "Corpos que pesam: sobre os limites discursivos do 'sexo"”. In: LOURO, Guacira Lopes. (org.). O corpo educado Pedagogias da sexualidade. Belo Horizonte: Autêntica Editora, 2001. p. 153-172.

. Problemas de Gênero: feminismo e subversão da identidade. Rio de Janeiro: Civilização Brasileira, 2003. Tradução de Renato Aguiar.

CRENSHAW, Kimberle. Mapping the margins: Intersctionality, identity politics and violence against woman of color. Stanfor Law Review, v. 43, jul., 1991.

CIDREIRA, Renata Pitombo. Os sentidos da moda: vestuário, comunicação e cultura. São Paulo: Annablume, 2005.

COLLING, Leonardo. "A naturalidade é uma pose tão difícil de se manter" - apontamentos para pensar Homofobia e Direitos no Brasil 
hoje. Texto apresentado na mesa redonda Homofobia e Direitos no Brasil hoje, realizada no V Congresso da Associação Brasileira de Estudos da Homocultura, no dia 26 de novembro de 2010, em Natal. Disponível em http://politicasdocus.com/index.php/downloads/category/1artigos?download=7:a-naturalidade-e-uma-pose-tao-dificil-de-semanter-apontamentos-para-pensar-homofobia-e-direitos-no-brasil-hoje

A igualdade não faz o meu gênero - Em defesa das políticas das diferenças para o respeito à diversidade sexual e de gênero no Brasil. In. Revista Contemporânea, v. 3, n. 2., São Carlos/SP, 2013.

Produção em alta e pouca influência: reflexões sobre a produção de conhecimento sobre diversidade sexual e de gênero e seus impactos no Brasil. Texto lido na mesa redonda Produção do conhecimento sobre diversidade sexual e de gênero: ativismo político-acadêmico realizada na Universidade de Rio Grande, durante o VII Congresso Internacional de Estudos sobre a Diversidade Sexual e de Gênero da ABEH no dia 8 de maio de 2014.

Quatro dicas preliminares para transar a genealogia do queer no Brasil. In. BENTO, Berenice; FELIX-SILVA, Antônio Vladimir. (orgs.). Desfazendo Gênero: subjetividade, cidadania, transfeminismo. Natal: EDUFRN, 2015. p. 223-242

CRENSHAW, K. Demarginalizing the Intersection of Race and Sex: A Black Feminist Critique of Antidiscrimination Doctrine, Feminist Theory and Antiracist Politics. The University of Chicago Legal Forum, v. 1989, p. $139-168,1989$.

FERNANDES, Fábio. A alma encantadora do Beco ou as crônicas de um errante vagabundo. Dissertação apresentada a Pós-Graduação Multidisciplinar em Cultura e Sociedade, na Universidade Federal da Bahia, Salvador, 2014.

LOURO, Guacira Lopes. Teoria queer: uma política pós-identitária para a educação. In. Revista Estudos Feministas, v.9, n. 2, p. 541-553, 2001.

Um corpo estranho: ensaios sobre sexualidade $e$ a teoria Queer. Belo Horizonte: Autêntica, 2004.

MARIA APARECIDA no carnaval. Jomard Muniz de Britto, 1974.

MESQUITA, Ralph Ribeiro. Entre homens, mulheres e deuses: identidade, gênero e (homo)sexualidade no contexto religioso afro- 
brasileiro. In. Revista Gênero. Niterói, v. 4, n. 2, p. 95-117, 2004. Disponível

http://www.revistagenero.uff.br/index.php/revistagenero/article/viewFi le/248/168. Acesso em 11 de dezembro de 2016.

MISKOLCI, Richard. A Teoria Queer e a Sociologia: o desafio de uma analítica da normalização. In. Revista Sociologias. n. 21, Porto Alegre, jan/jun 2009.

. Não Somos, Queremos - Reflexões queer sobre a Política Sexual Brasileira Contemporânea. In: Leandro Colling. (Org.). Stonewall 40 + o que no Brasil?. Salvador: EDUFBA, 2011, p. 37-56.

. Um saber insurgente ao sul do Equador. Periódicus, n. 1, maio/out., 2014.

. Nem sempre fomos queer, nunca fomos parte da nação. In. BENTO, Berenice; FELIX-SILVA, Antônio Vladimir. (orgs.). Desfazendo Gênero: subjetividade, cidadania, transfeminismo. Natal: EDUFRN, 2015a. p. 243-261.

. Palestra apresentada no I Seminário Queer, realizada no dia 10 de setembro de 2015b no SESC Vila Maria em São Paulo/SP. Disponível em https://www.youtube.com/watch?v=zj7yp-tRpcw. Acessado em 6 de janeiro de 2016.

PELÚCIO, Larissa. Subalterno quem, cara pálida? Apontamentos às margens sobre pós-colonialismos, feminismos e estudos queer. Revista Contemporânea, v. 2, n. 2, Jul-Dez. 2012, p. 395-418 - Disponível em http://www.contemporanea.ufscar.br/index.php/contemporanea/article/ view/89/54http://www.contemporanea.ufscar.br/index.php/contempora nea/article/view/89/54

Traduções e torções ou o que se quer dizer quando dizemos queer no Brasil? In. Revista Periódicus, vol. 1, n. 1. Dossiê Cartografias dos estudos queer na Ibero-América. maio-outubro de 2014.

OUTRAS CENAS da vida brasileira, Dir. Jomard Muniz de Britto, 1983.

PEREIRA, Pedro Paulo Gomes. Queer nos trópicos. Revista Contemporânea, v. 2, n. 2, Jul-Dez. 2012, p, 371 a 394. Disponível em http://www.contemporanea.ufscar.br/index.php/contemporanea/article/ view/88/53http://www.contemporanea.ufscar.br/index.php/contempora nea/article/view/88/53 
PRANDO, Alisson. Problemas de gênero e excessos academicistas: I Seminário de Teoria Queer Parte II. Set. De 2015. Disponível em http://www.discopunisher.com/2015/09/problemas-de-genero-eexcessos_12.html. Acessado em 6 de janeiro de 2015.

SÁEZ, Javier. "El contexto sociopolítico de surgimento de la teoría queer”. In: CÓRDOBA, David, SÁEZ, Javier e VIDARTE, Paco. Teoría queer: políticas bolleras, maricas, trans, mestizas. Madrid: Ed. Egales, 2007. p.p. 67-76.

SANT`ANA, Tiago dos Santos de. Outras cenas do queer à brasileira: o grito gongadeiro de Jomard Muniz de Britto no cinema da Recinfernália. Dissertação apresentada ao Programa de Pós-Graduação Multidisciplinar em Cultura e Sociedade da Universidade Federal da Bahia. Salvador, 2016.

SANTOS, Milton Silva dos. Mito, possessão e sexualidade no candomblé. In. Revista Nures. n. 8, Santos, Jan-abr de 2008. Disponível em http://www.pucsp.br/revistanures/revista8/nures8_milton_02.pdf. Acesso em 08 de dezembro de 2015.

TREVISAN, João Silvério. Devassos no paraíso: A homossexualidade no Brasil, da colônia à atualidade. 5. ed. Rio de Janeiro: Ed. Record, 2002.

Recebido em 14/11/2016

Aprovado em 11/12/2016 